\title{
Perception of Graduate and Undergraduate Students in the Effective Utilization of Social Networking Sites
}

\author{
Renaissance Ahmed Sayma \\ Lecturer, Department of English, Comilla University, Cumilla, Bangladesh.
}

\begin{abstract}
The study selected Facebook as a representative of Social Networking Sites because Facebook is the most popular platform for sharing opinions, views, and ideas. A lion share of daily time is spent on surfing Facebook by a large number of university students in Bangladesh. This study endeavors to focus on Facebook's positive impacts on students' lifestyle, education, social and economic life, and negative impacts on health and personal relationships. It also investigates whether Facebook could be an essential tool for e-learning or not. 150 students took part in the survey and data was collected through a set of questionnaire. During data analysis, both qualitative and quantitative methods were applied. This study significantly finds that students reflect a high positive opinion, a low negative attitude, and a moderate addiction on Facebook. The study also revealed that Facebook could be utilized to enhance their academic performance and help them get the latest study-related information, share materials, and encourage collaborative learning, group studies, and interaction. It is also found that excessive and imbalanced use of Facebook affects the students' health and family life. The researcher will try to provide some recommendations for the users to harvest a healthy benefit by using Facebook in a balanced way.
\end{abstract}

Keywords: Facebook, e-learning, positive and negative impact, health, graduate, undergraduate students DOI: $10.7176 /$ JLLL/69-08

Publication date:June 30th 2020

\section{Introduction}

Social Networking Sites (SNSs) are connecting the planet in a way as no other generation has experienced before. The most acknowledged SNSs are Facebook, Twitter, Instagram, MySpace, IMO, Viber, Messenger, WhatsApp, Google +, Skype, YouTube, Academia.edu, and LinkedIn. The utility of those online sites among the students is turning out to be progressively acknowledged and trendy because these sites allow them to have access to information, group discussion, resource sharing, and amusement. However, SNSs have both positive and negative consequences on the students' academic and private life. By surveying students' utilization of Facebook as a specialized apparatus, we aspire to outline how students are currently incorporating Facebook into their variety of ordinary exercises.

More than $50 \%$ of the students use a social networking site several times to upload or download photos or videos, get information concerning their profession or educational work, chat with pals, watch movies, and do research (Sheldon,2008). While the students utilize these sites as a leisure time activity, it might harm their educational performance (Mingle \& Adams, 2015). When they apply jargon language in the text messages, it affects their writing skills, spelling, and grammatical understanding (Mingle \& Adams, 2015). Moreover, who uses it repeatedly may have more stomach aches, insomnia, uneasiness, gloominess, and isolation from real life (Larry D., 2011b). Additionally, excessive use and abuse of these sites cause moral corruption, mental disorders, and violent tendencies among the users (Larry D., 2011a). The University culture nurtures Facebook, hugs it, and has transformed the site into a standard of living rather than a pastime. The present study will mainly emphasize the usage of social networking sites and the visible positive and negative impact on the academic and the personal and social lives of the graduate and undergraduate students of Bangladesh.

\subsection{Statement of Problem}

The majority of the parents is worried about the increasing use of Facebook by their children and is confused whether their children are paying enough attention to their studies. This research is carried out to determine the impact of the use of the student's social networks on their study and overall life. For which reasons do Bangladeshi students use social media? Does the use of social media condense the amount of time the students dedicate to their education? Do social media have any positive contribution to the students' studies? These form the core problems this study seeks to investigate and explain steadily. This study has been designed to recognize how the excessive use of social media can affect university students' personal and social life. The result of this research optimistically will make awareness among university students accessing social media.

To achieve the goal of the study, the researcher has organized a survey with the help of the following core inquiries:

1) What number of active social networking sites (SNSs) does each student has and which they most regularly use one among these accounts? What amount of time in a specific day is spent by the students 
in these social networking accounts?

2) Do the students think social networking sites can be a useful tool for e-learning? According to Students' perspectives, are there any educational advantages of using Facebook?

3) What is the contribution of Facebook for the development of students' social relationships?

4) While utilizing Facebook, do students face any challenges/threats?

5) How can the excessive use of Facebook affect Students' in their Academic, Personal life, Health, and Social life?

\subsection{Significance}

This study will enhance awareness about the problems that are caused by excessive use of Facebook among the graduate and undergraduate students of Bangladesh. The study will contribute to develop a balanced and quality utilization of Facebook. It will also help to realize how the deliberate use of Facebook will make sure of the persistence of the students' time, merit and both the physical and mental health.

\section{Literature Review}

The qualitative study carried out by Selwyn (2009) on United Kingdom' Tertiary Level students using Facebook reported that they used Facebook for critical learning, exchanging ideas, expanding moral support, and contradictorily encouraging themselves to be academically detached or unskilled. Helou \& Rahim (2014) conducted a study on the 'influence of social networking sites on the student's academic performance'. According to this study, social networking sites have built a new social facet, where individuals can enlarge their social awareness by keeping in touch with old friends, making new friends, providing new data or products, and gathering information in other aspects of everyday life.

Boyd \& Ellison (2007) identified in a study that teenagers have welcomed these sites to connect with their fellows, share information, reshape their personalities, and showcase their social lives.

Zwart et al. (2011) identified the benefits of using social networking sites, including the creation of room for creativity among students, encouraging more significant social interaction, reducing barriers to group interaction and communications, and increasing the technological competency levels of its users. In a study, Yunus et al. (2013) argued that students could gain more vocabulary and improve their writing skills, can exchange assignments and resources, and discuss academic work and other social networking sites. Thus, the positive effects are helping students to improve their knowledge and social skills.

SNSs platforms permit the expansion of learning conversation outside the formal classroom setting, thus promoting deeper learning as young people not only connect with the material for longer but are more expected to relate to it and include it into their everyday lives (Notley \&Tacchi, 2005). Many researchers established a positive relationship between the use of SNSs and the academic performance of student users. Students who used SNSs scored higher on reading skills tests and had higher grades as well. Also, it has been found that Facebook usage is helpful for a cure in several psychological crises, including low life satisfaction and low self-respect (Ellison et al., 2007). Ginsburg-Block et al. (2006) argue that most participant learning experience on SNSs is associated with social learning. Hence, social learning outcomes comprise the majority of learning outcomes. Cognitively, they learn how to artistically solve problems via information searching and online friends' assist. Emotionally, they feel free to reveal and present themselves, share the sentiment with others, and grow more confidence from champions. Finally, they develop their social skill and collaborative skill and also more willing to share their knowledge with fellows. He continues that these are useful for their well-being development, such as self-esteem and contentment with life. Though the students do not clarify the academic learning outcomes from online social networking, it cannot refute the impact of online social networking on academic learning outcomes.

By observing 137 Private university students, Mostafa (2011) has found in his study that $56.2 \%$ of students used the internet for educational purposes, $15.3 \%$ for research purposes, $10.2 \%$ for communication purposes, $16.8 \%$ for entertainment purposes and remaining $1.5 \%$ for other purposes. He also identified in his research that most $(82.5 \%)$ of the students responded that the internet could play a significant role in the ground of education.

There is a negative relationship between time spent by the students on social networks and their academic performance. A study conducted by Wang et al. (2011) indicated that 57\% of 102 students who use social networking sites reduce their productivity and performance. Larry D. Rosen (2011) conducted a study on social networking's good and bad impacts on kids. The study's major findings revealed that these sites' excessive users show more narcissistic tendencies, antisocial behaviors, mania, and aggressive tendencies.

SNSs can be exploited for plagiarism, cheating, harassment, and other types of academic and social wrongdoing (Anderson, 2010). Overall, a picture of risk and danger emerges. As Selwyn (2009) notes, SNSs can place children 
at risk of harming themselves and others. Possible risks identified with the use of SNSs include risks of psychological disorders and health problems, i.e. social loneliness, anxiety, hopelessness, time mismanagement, poor eating habits, and lack of physical exercise; more significant short attention spans and threatened higherorder reasoning skills such as attention, determination, and analytical reasoning among frequent users of SNSs; a tendency to overvalue one's ability to multitask and manage projects; and technology being seen as a replacement for the analytical reasoning process (Brenner, 1997; Connolly, 2011; Kraut,Patterson, Lundmark, Kiesler, Mukophadhyay, \& Scherlis, 1998; Rosen, 2011; Young, 1996; and Zwart, et al.,, 2011).

Previous researchers have appreciably dealt with and recognized diverse aspects of internet use in Bangladesh. Rahman, (2002) has assessed the internet and its access; Roknuzzaman (2006) has conducted an investigation on internet access in public university; Alam, Kabir, and Elizabeth (2006) have observed the execution and assessment of e-learning; Islam and Selim (2006) have scrutinized the existing status and visions for e-learning in the encouragement of higher education; Mohseni, Dowra and Haghighat(2008) have inspected whether the use of internet is making people socially cut off or not; Mostofa (2011) has scanned the access and use of internet among business students of a private university of Bangladesh; Mahmud (2011) has detected the private university student's approaches towards internet; But none of them have investigated the impacts of the use of SNS on Bangladeshi students' academic performance in any of their aforesaid studies; except, Asad, Mamun \& Clement (2012) who have surveyed the effect of social networking sites to the lifestyles of teachers and students.

This research will shed light on the effective utilization of Facebook, as the representative of SNSs and its' impact on the social and economic, academic, personal and health life of graduate and undergraduate students of Bangladesh.

\section{Research Methodology}

a) Research method: Quantitative and Qualitative

b) Question type: Close-ended questions, LIKERT Scale

c) The population: under-graduation and graduation level students of Cumilla district in Bangladesh.

d) The sample of the study was the graduate level (18-28 years old) students.

e) The sample size was 150 students consisting of both male and female participants. Among that, 100 respondents are from the target group of 18-28 years old. The rest 50 respondents are more than 28 years old.

f) The study sample consists of 150 respondents from 4 colleges and universities of Cumilla district in Bangladesh, such as Comilla University, Lalmai Govt College, Comilla Victoria College, and Comilla Govt College.

g) A well-structured questionnaire was designed to gather data and information from the respondents. It was divided into five sections, such as Section 1, 2,3,4,5. Section 1 provided respondents' demographic information, such as age, gender, educational status. Section 2 contained the positive and negative impact on students' academic life. Section 3 and 4 included the questions whether SNSs have any impact on creating the social relationship, Section-5 analyzed the threats students' face from using Social Networking Sites and whether the use of Facebook is in the normal range or addiction level. The questionnaire is presented in Appendix 1.

h) The researcher created an online questionnaire and distributed it to the students of Cumilla district. The data was collected in Google docs. After the collection of data, the total responses were 200 and after the unnecessary data cleaning, there were useful 150 responses.

i) Both primary and secondary sources were Data. Primary data were collected through a questionnaire survey. Five point Likert scale was used to conduct the survey, where 1 stands for strongly agree/Always, 2 for agree/Often, 3 for neutral/Frequently, 4 for disagree/Occasionally, and 5 stands for strongly disagree/Rarely. Secondary data were collected from different websites, published articles in the journals, conference papers, and books.

\section{Data Analysis and Discussion}

\subsection{Demographic Questionnaire}

The questionnaire's opening was with demographical questions; the gender and the age of the respondents were asked. Data was collected impartial from both sex groups to make the study exemplary. There were $59.8 \%$ female 
and $40.2 \%$ male respondents. We get confirmation from the study that female students were more disturbed with social media than the male students. Age categorization of those engaged in the survey is from less than 18-yearold $0.9 \%, 18-21$ years old $70.1 \%, 22-25$ years old $27.1 \%$ and above $1.9 \%$.

\subsection{Background knowledge about Performance of SNSs Users}

The researcher used a close-ended questionnaire to find out data from teachers. The questionnaire was distributed to teachers of three universities (Comilla, Britannia, and National University). The teachers' questionnaires included 25 questions with fixed alternatives.

a) Most Using Social Networking Sites

The following figure will reveal the depicted portrayal of social media individuals in Bangladesh. The sample data were found by the study, which was done among 150 students. It shows the most using platform of social networking site. Fig 1shows that 55.1\% use Facebook, 37.4\% use YouTube, 3.7\% use WhatsApp and rest are LinkedIn and Blogs use.

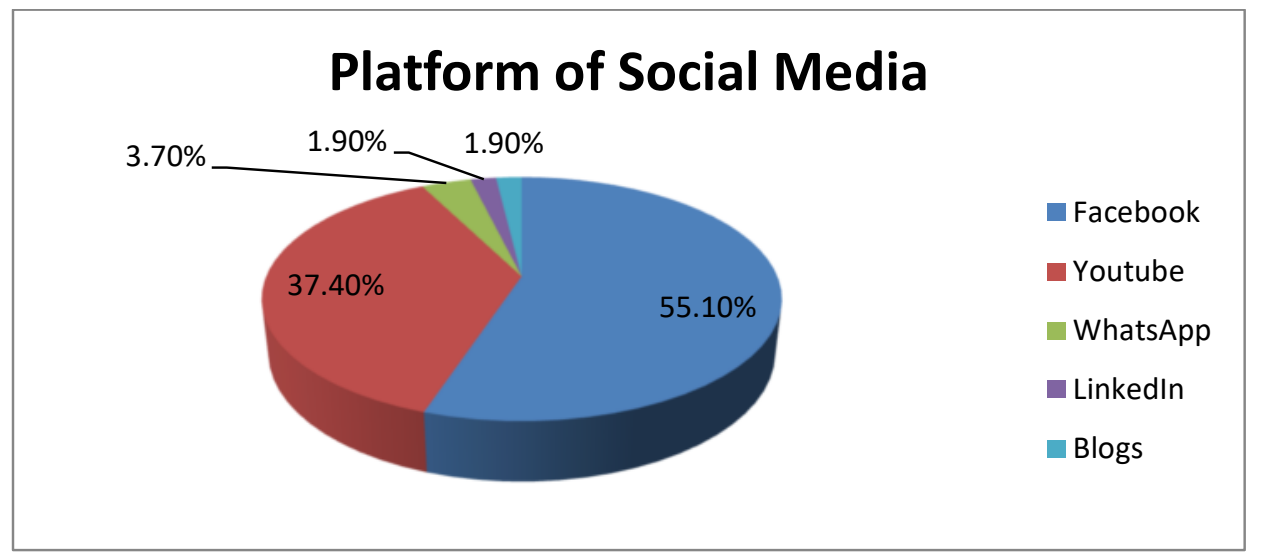

Figure 1: Most Using Social Networking Sites

b) Facebook connected years:

The next question was whether they are known to Facebook and its' usage or not. $100 \%$ of the respondents answered that all of them use Facebook as one of their most favorable Social Networking Sites. The researcher analyzed the next question, where the undergraduate students are asked how long they have been using Facebook. Around 30.8\% of respondents agreed that they are using Facebook as beginner- level users and started it just one or two years ago. Only $8.4 \%$ of respondents were using Facebook for more than seven years old.

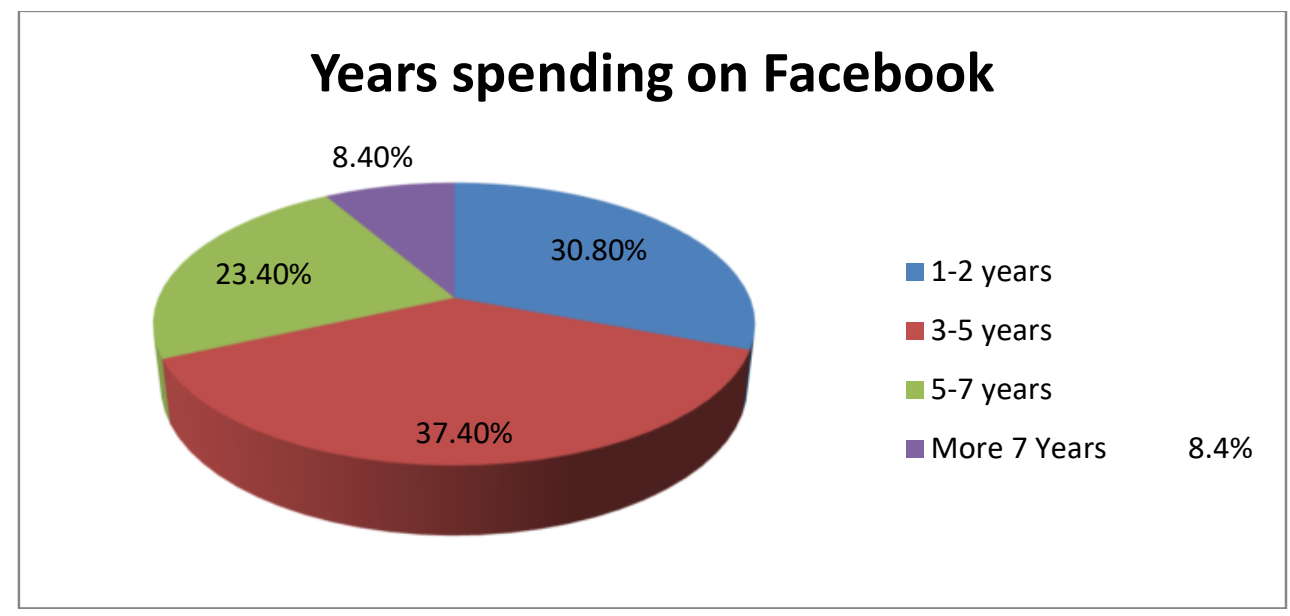

Figure 2: Number of Years spends on Facebook

c) Hours Spending on Facebook per day

The respondents were asked how many hours do they spend on Facebook now, and the following pie chart shows the number of hours they spend on Facebook. Fig 5 illustrates time spending on social media per day. Time spending on social media refers to how long they were logged on the site. $45.8 \%$ of users use social 
media for 1 to 2 hours per day. $37.4 \%$ uses 3 to 5 hours per day. 9.3\%use it for $0-60$ minutes. $4.7 \%$ use it for 6 to 7 hours, and the rest, $2.8 \%$ use it for more than 8 hours.

\section{Hours/per day on Facebook}

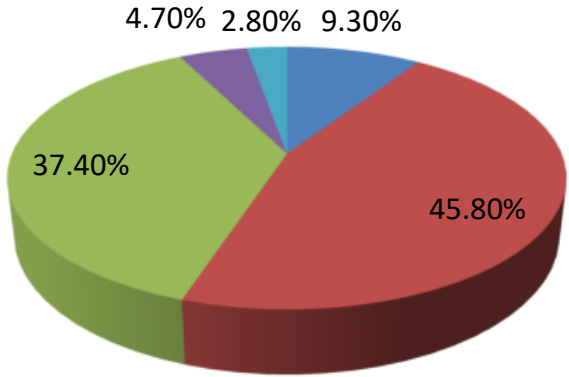

0-1 hour

1-2 hours

3-5 hours

6-7 hours

More $8 \mathrm{hr}$

Figure 3: Hours spend on Facebook per day

d) Average friends on Facebook:

The average friend count of the target group is 500-1500.

e) Minutes spending on Facebook per login:

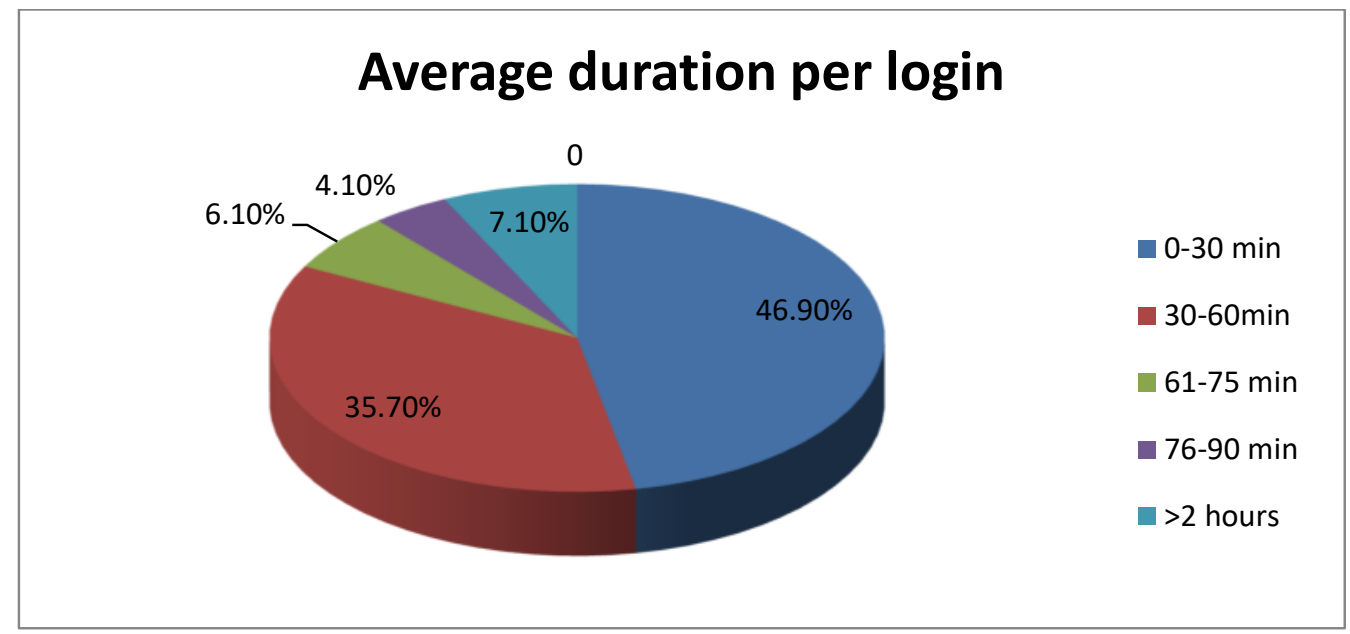

Figure 4: Time spending on Facebook per login

They spent an average of 30 minutes on Facebook per session of logins.

4.3 Facebook Addicted or not

To know the addictive nature of Facebook's use, the researcher will analyze the section 5 and its' questions no $5,6,8,10,12,13,15,20$. (Table 1)

To assess the level of addiction, users answered the following questions using this scale:

$0=$ Rarely/Strongly Disagree

$2.5=$ Occasionally/Disagree

$5=$ Frequently $/$ Neutral

$7.5=$ Often $/$ Agree

$10=$ Always/Strongly Agree

After managing the questions and receiving answers, numbers were added for each response to get a final score.

Final Score $=\sum$ (Response weight $\mathrm{x}$ percentage vote for response $) / 100$

The higher the score range, the greater the level of addiction, as follows:

Normal Range: 0-2.5 Points; Mild: 2.5-5 points

Moderate: 5-7.5 points; Severe: $7.5-10$ points 
Table 1: Is Facebook Addicted?

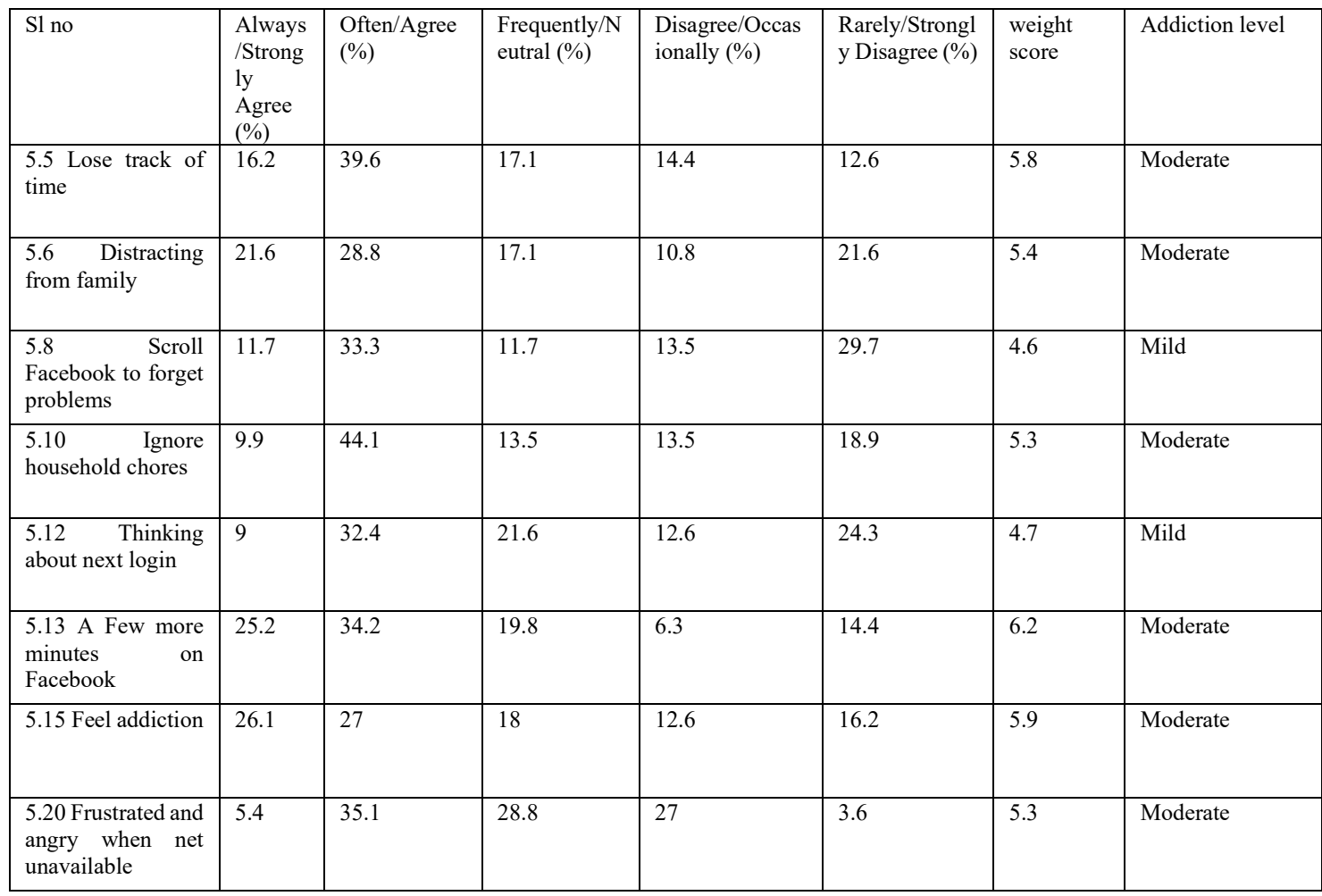

From above Table 1, we can say that most of the respondents are moderately addicted, and few are mildly addicted to Facebook.

If we analyze their behavior towards Facebook, we find that more than half of the respondents always struggled to cut down the use of Facebook. It was also found that $39.1 \%$ of the respondents agreed that they lose track of time while using Facebook. They attempt several times to cut down the excessive use of Facebook but fail to win over. In the next question, more than $50.4 \%$ of respondents always or often get themselves distracting from family because of their excessive use of Facebook. It was also found that $45 \%$ of them always or often scroll Facebook to forget their problems. Instead of facing the problems to solve it in real life, they like to indulge in a virtual solution that is scrolling Facebook without any aim. They use Facebook as a means to avoid their issues. Along with distracting from family, 54\% of the respondents opine that they always or often ignore household chores to spend more time on Facebook. $40 \%$ of them always or often think about login next time again. They cannot help but controlling time for using Facebook. It was also found that $59.4 \%$ of them generated the behavior of convincing themselves by saying "a few more minutes" to use Facebook for a more extended period. When social networking sites are not available, most of the respondents feel angry or suffer from depression and loneliness. The last question was whether the students feel addicted or not, then more than half of the responds strongly agreed that they always or often prefer to socialize on Facebook than meeting them in real life.

4.4 Reasons for Using Social Media (Facebook) by Tertiary Level Student

On the other hand, figure-5 indicates the motives of using social media, especially Facebook, by Tertiary level students of Bangladesh. According to the data, 59.8\% of the users' community used social media for getting relevant documents regarding their education and, $46.1 \%$ used it for getting enjoyments, chatting with virtual friends, and uploading photos or status. $10.8 \%$ of the respondents use Facebook for searching and making new national or international level friends. However, there was business use of social media as $3.9 \%$ of them asserted that they used such media to share their extra-curricular qualities to sell products and earn money from social media, $34.3 \%$ shared social events over the media to raise awareness in the society. But there was another category of the users, where $17.6 \%$ participants used social media for killing the time. 


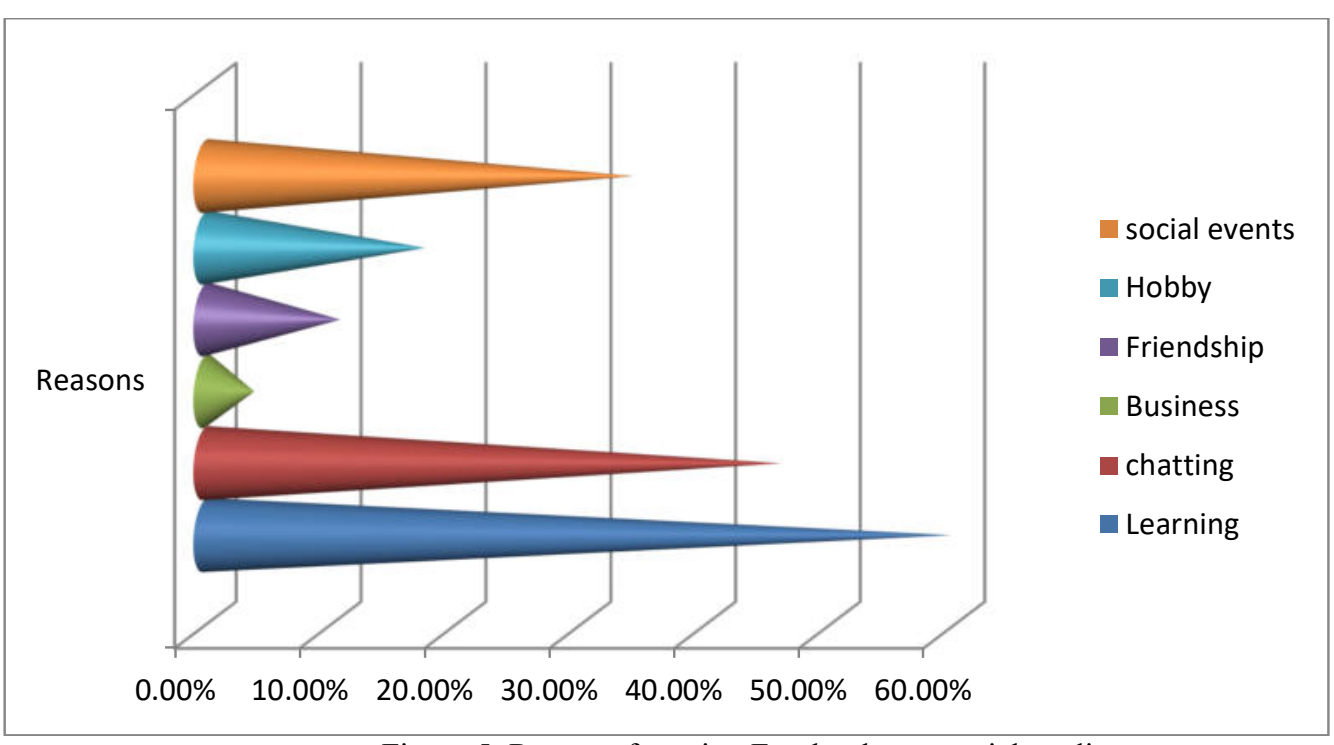

Figure 5: Reasons for using Facebook as a social media

4.5 Impact on Students' Academic Life and Education

The study will examine both the positive and negative impact of Facebook on Students' Academic life. The respondents are asked to answer the 28 questions in Section 2, after collecting data, the researcher will categorize whether using Facebook has any advantage or disadvantage on Students' academic performance.

At first, it is necessary to know how many hours; they spend on Facebook for learning purposes. On questionnaire no $2.23,35 \%$ of them replied that they spend 1 hour for learning purposes. $28.2 \%$ of them use only 30 minutes for academic purposes.

From the questionnaire no 2.1, the respondents categorize the main barriers that hinder the adoption of social media in the classrooms at their university. $34.8 \%$ of them respond that internet or technical issue is the main barrier to hinder adoption of Facebook in the classroom environment. The next significant barrier is that students misuse of social media, and it might be a threat to apply Facebook in the classroom. $29.5 \%$ scored for fear of misusing the social networking sites in academic institutions. The rest barriers are time (15.2\%), Content (6.3\%), and Curriculum (14.3\%).

The study (Appendix 1, Section2) analyzed individual aspects and found that except a few disadvantages, Facebook has a positive impact on students' academic life. If students can overcome those problems, Facebook will be proved as an essential tool for e-learning. Individual aspects of the questionnaire are given below:

- Teachers provide the link, materials to students through using social media: The data shows that around $72.1 \%$ of the respondents agreed (questionnaire no 2.11 ) that their teachers provide the relevant courserelated materials through using Facebook.

- Students can consult and get information from each other: Around $66.7 \%$ of respondents agreed, and $6.9 \%$ strongly agreed (questionnaire no 2.13 ) that students can consult with classmates, friends, or respective course teachers and get supportive help regarding their lectures and other questions. In that viewpoint, Facebook is an essential tool of e-learning, according to students' perspectives.

- Facebook group, an effective medium of teaching and learning: In a Facebook group, answers are saved, so that students can look them up later. After analyzing the questionnaire no 2.14, the researcher found that around $66.7 \%$ agreed that they benefited from the Facebook group as learning material. If any students fail to access in Facebook due to lack of $\mathrm{Mb}$, they do not feel worries, as they can go to the Facebook group anytime and look up the post later. Thus the students become benefited by Facebook, and it helps them to note down the necessary points. Another important fact is that, to participate in a Facebook group, a teacher does not need to become friends with the students.

- Instant feedback: Unlike other social networking sites, Facebook is famous for its' instant feedback (questionnaire no 2.16). Students get instant feedback from their teachers. Feedback is an important 
technique to make student understood their mistakes or lacking. Getting instant feedback, students can take proper preparation for their examinations. $66.6 \%$ of them agreed and $8.8 \%$ strongly agreed that Facebook can be an essential e-learning tool because of instant feedback.

- Facebook as a helpline service: In Social media, students ask for help/advice on Assignments, solving problems, projects, etc. In the questionnaire no of 2.9 (Section2), 60.4\% agreed, and 16.2\% strongly agreed that they get instant help or advice from their teachers or classmates regarding assignments, solving problems or projects. On the questionnaire no 2.20 , the respondents agreed $69.6 \%$ that they always rely on Facebook as a mean educational help.

- Promote student collaboration: On questionnaire no 2.24, it is found that $59.8 \%$ agreed, and $6.9 \%$ strongly agreed that Facebook promotes student collaboration. On questionnaire no 2.6, it has found that they find Facebook helpful to complete their assignment where students share and obtain information, links, or course-related files. More than $50 \%$ of students agreed that for them, Facebook is an essential tool for elearning. Through social media, they gain collaboration between them and come forward to help each other in academic life.

- The Best way for teachers to reach all the students: From the demographic analysis, we found that all of the students use Facebook. Facebook is one of their most favorite social networking sites. Also, through using Facebook, both teachers and students can get an instant notification. In order to achieve students' attention, nothing but Facebook can be the best way for teachers to reach all the students at a time. On questionnaire no 2.27 , the respondents confirmed that $49 \%$ of them agreed, and $13.7 \%$ strongly agreed with the fact.

- Facebook as a means to get updated materials: In this regard, Facebook is helpful for students as $15.3 \%$ of students always, and $49.5 \%$ of students often (questionnaire no 2.5) rely on Facebook to get updated information about required and non-required course -related materials.

- Facebook establishes the interaction between teachers and parents: From the survey on questionnaire no 2.28 , it is found that Facebook establishes a functional interaction between the teachers and parents. Parents get informed by the teachers about the academic results of their students. Around $46.1 \%$ of students agreed that Facebook establishes the interaction between teachers and parents, and both of them as a team can monitor students.

- Teachers make announcements: Through using social media like Facebook, both the teachers and students get to know each other. Also students get advice and help from teachers regarding their assignments or course materials. Teachers also announce the deadline of assignment on Facebook, so that students become conscious of submitting their assignments on due time. $52.3 \%$ of them agreed (See Appendix 1, questionnaire no 2.19).

- A Highly motivating and entertaining way of teaching: Apart from the regular classical environment of the classroom, Facebook assists as a mixture of both learning and laughter. Through Facebook, students get to know their teachers outside the classroom. They feel confident here to ask questions and get information. From students' perspectives, on the questionnaire no $2.4,44.1 \%$ of students agreed that social media is a highly motivating and entertaining way of teaching, especially for university learners.

- Shy students get confident: More than $54.9 \%$ students assert that they feel confident in asking questions on Facebook. (See Appendix 1, questionnaire no 2.12)

- The conversation moved from Facebook to Class, Class to Facebook: The last but not the least effect of using Facebook as an e-learning tool is that students get engaged even after the ending of the classroom. Furthermore, they show interest to discuss lectures or examination topics on Facebook. Thus students can give more time to study. To the answer of questionnaire no 2.15 , most of the students often or always move their conversation from class to Facebook and then Facebook to class.

- The Teacher acts as a Mentor : Around $61.6 \%$ of students agreed that social media helps them to ask course-related questions to teachers (Appendix 1, questionnaire no 2.07). After getting advice from their teachers, students feel confident, and they discovered that using Facebook can lower students' anxiety towards writing in English. 
From the survey, the researcher also outlined a few disadvantages of using Facebook, which create a negative impact on Students' Academic performance:

○ Time- consuming: Although the study found that Facebook is an important tool for e-learning, using this social media in class is time consuming, according to students perspective. $50 \%$ of students affirmed this negative side. (Appendix 1, ques no 2.02)

○ Lower grade: Another negative aspect is found, after analyzing the questionnaire no 2.18 that $54.9 \%$ of students agreed, and $23.5 \%$ strongly agreed that using excessive Facebook hamper their academic results. They also regret that if they spent less time on Facebook, they would have better grades.

- Lesser time to their studies: The more they engage in Facebook, the less time they spend on their study. As a result they gain poor marks in their examination. The study of the questionnaire no 2.25 found that $56.9 \%$ of students agreed that they as Facebook users devote lesser time to their studies. The next questions (2.26) calculated that more than $50 \%$ of students agreed that excessive use of Social Networking Sites users scored the lower grades.

- Feel hesitant to be judged before classmates: Most of the time, shy students feel hesitant to ask questions on Facebook because it is open to all of their classmates. If the teacher provides error correction, students feel hesitant to post and to be judged by teachers and students. $66.7 \%$ of students agreed that they feel hesitant to be judged before all (ques no 2.10).

4.6 Impact on Students' Social relationship

Facebook is one of the most accepted social media, which helps to make the social relationships. It is designed to boost communication among their users. Especially its availability on many mobile devices allows users to continually stay in touch with friends, families, and other associates as long as there is access to the Internet. The analysis was taken from the collected data of Section 3 of Appendix 1. There are almost 15 questions in the questionnaire, and the benefits are given below:

- Facebook for networking \& connectivity: From the questionnaire no 3.1, it is found that most students around $37.8 \%$ always rely on Facebook as mean networking \& connectivity over other SNSs. Moreover, consecutively, $31.5 \%$ of students often find Facebook helpful in this regard. From this data, we can conclude that almost more than $69.6 \%$ of respondents use Facebook for communication purposes. Thus, if the user gets uncontrolled, the users become Facebook addicts.

- Facebook for an invitation to social events : Around $13.7 \%$ of the students strongly agreed they find Facebook as means to get invited to social events. Moreover, consecutively $60.8 \%$ of students agreed they find Facebook helpful in this regard. These social events help them to build up public opinion. (Appendix1, ques no 3.12)

- Getting help related to charity and blood donors through Facebook : After analyzing 3.8, according to students' perspective, $43.2 \%$ of students often and $29.7 \%$ of students always find Facebook helpful concerning noble social causes (charity / blood donors). For them, as Facebook is accessible, convenient, 24/7 communication, they can seek for help anytime and get instant help regarding blood donation. Also, students as a community create social events and arrange charity for the needy through Facebook.

- Reunite lost or old friends: Question no 3.11 focuses on the importance of Facebook in finding lost or old friends. Around $56.8 \%$ of students always and $30.6 \%$ of students often find Facebook as magic in finding and reuniting with lost friends and maintaining social bondage.

- Creating Social Awareness: More than 69.6\% of students agreed on question no 3.15 that Facebook usage help students to create awareness in society regarding any burning issue.

- Minimize the cultural gap: Most of the students find Facebook as an effective means to make new friends. Through the Facebook profile, they can easily make international level friends too. Thus, Facebook helps to minimize the cultural gap. If we look at question no $3.10,56.9 \%$ of students agreed that minimizing the cultural gap; Facebook helps them to make a wider scope for communication.

- Communicate with alumni: The students find Facebook helpful in reuniting with alumni. This study shows that around $70.6 \%$ of students agreed (question no 3.5) that they rely on Facebook as means to get 
community help \& advice. Moreover, consecutively, 16.7\% of students often find Facebook helpful in this regard.

\subsection{Impact on Online Business}

In using social media, there are also a few business impacts. In the first question of Section 4, 29.7\% of students always and $37.8 \%$ of students often rely on Facebook in finding online job circulars. In the second question, more than half of the students $(52.1 \%$ ) respond that they rarely use Facebook for running business, whereas only $34 \%$ of students always or often use Facebook for running a business. In the third question, only $14.9 \%$ of students agreed that they earn some extra money by running a business page in Facebook. To follow-up business group, the students spend an average 30 minutes on Facebook. In the next question, 30.4\% of students often find confidence in online shopping through using social media. $35.3 \%$ of students respond they do not feel confident as sometimes they are cheated on by online shopping. The final question was asked whether this online business hampers their study or not. Around $40.2 \%$ students remained neutral and $35.3 \%$ of students agreed that online business hampers their study as they have to spend time on follow-up.

4.8 Negative Impact/Threats of Facebook After analyzing section 5 of the questionnaire, the researcher finds that Facebook has a negative impact on Students' personal life and health issues too. These adverse impacts are given below:

- Victim of Facebook account hacking: From 5.1, it's clear that around 13\% of students always or often are victims of Facebook account hacking while using Facebook.

- Victim of cyber-harassment or blackmailing: From 5.2, the researcher finds that around $35.1 \%$ of the students often and $5.4 \%$ of students always became a victim of cyberbullying and blackmailing while using Facebook. And 27\% of students occasionally and 3.6\% rarely were a victim of cyberbullying or blackmailing while using Facebook.

- Privacy issues: Privacy issue means other persons finding information about the user and user's family or stole user's images and videos or stalking. From 5.4, it is found that only $7.2 \%$ of students always face privacy issues while using Facebook. Furthermore, $14.4 \%$ of students have often faced privacy issues due to Facebook use.

- Lose track of time: Question no 5.5 shows that around $16.2 \%$ of the students always feel that they are wasting their valuable time on Facebook. And 39.6\% of students have often felt that they are wasting their time on Facebook.

- Disturbed by Fake Accounts: The data shows that $28.8 \%$ often and $21.6 \%$ always have been disturbed by the fake accounts.

4.9 Negative Impact on Students' Physical and Mental Health

The increase in the use of Facebook among university students inspired them to change their conduct and lifestyle. Lack of face-to-face communication may also lead to loneliness, depression, and other mental disorder. The extra time students are engaged with Facebook, and they are at a higher risk of being deprived of their sleep, a rise in depression or anxiety, and low self-esteem. The study continued to show that $24.3 \%$ of students often suffer from deterioration in health due to excessive use of Facebook, $36 \%$ of students often have suffered from insomnia, $30.6 \%$ of students often feel Headache, Eye problem, stress and dark circle for excessive use of Facebook; 30.6\% of students often and $11.7 \%$ of students always suffer from the emotional problems, mental depression, lack of face- to- face communication due to use of Facebook.( (Section 5 's question no 3, 11, 16, 17))

\subsection{Summary of responses:}

The overall response of the respondents is summarized in table 4. Each question contains a weighted score calculated by equation (1). The responses are then divided in four equal quartiles namely Upper quartile, upper mid quartile, lower mid quartile and lower quartile. figure 5 represents that the response for the extreme values had a minimal count ( 1 for lower and 4 for upper quartile). This indicates the propensity of people to refrain from the extreme responses. Also, from figure 8 it is evident that the responses follow a normalized bell-shaped curve which is right skewed, i.e. people tend to give more positive response than negative. The responses in upper mid quartile and lower mid quartile are counted as 48 and 11 respectively.

The last column of table A1 (in Appendix) indicates the ranks of the questions. It is seen from the responses that, question no $3.11,3.09,3.07,2.14$ and 3.01 had the best weighted score as responses and question no 5.01, 4.02, $4.03,5.03$ and 4.05 had the least weighted score as responses.

The Key to positive response in these questions is further explored. Four of these questions asked about the role 
of Facebook in communication, quick way of getting information and a way to get old friends back. Only 1 of top 5 responses involved getting the answers saved for later review: an academic perception. This perception indicates the students taking social media more as a communicating platform than an academic one.

The negative responses include issues like getting account hacked, deterioration of health, use as business page, making money by Facebook, confidence in online shopping etc. These responses indicates that nobody amongst the respondents have been a prey to negative impacts of Facebook use largely. The respondents are a control group with conscious and aware undergraduate and graduate students. This may be the reason behind negative responses. Also, one of the queries included health hazards which are often difficult to link with the use of Facebook.

In a nutshell, the respondents' positive view in replies makes us hopeful about the effective utilization of social media for academic purpose. However, some precautions and recommendations are needed which is mentioned in next section.

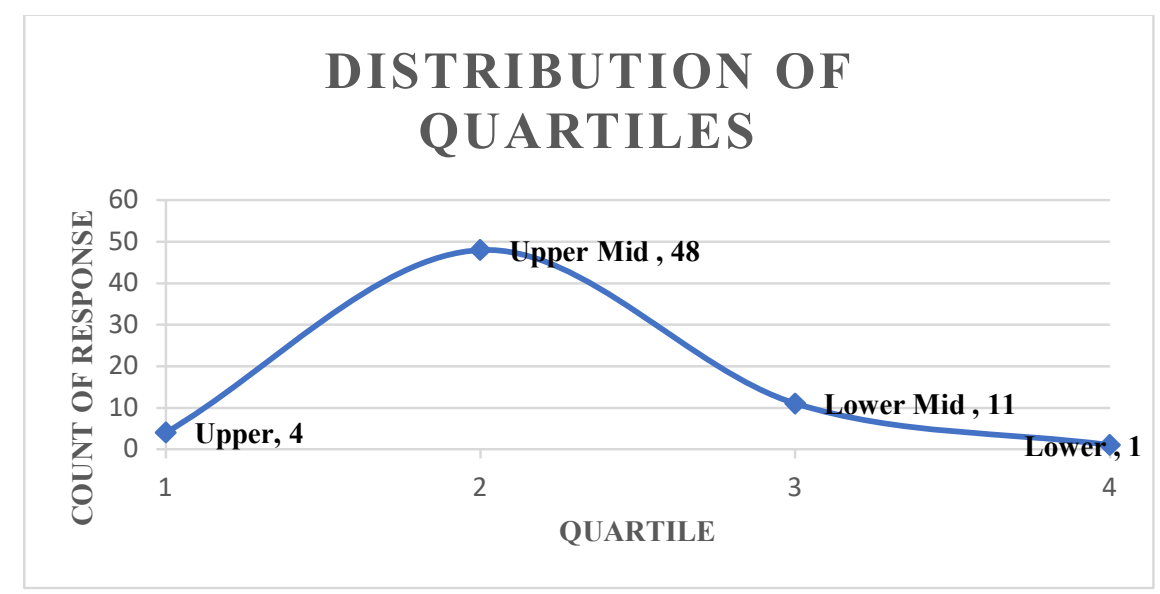

Figure 6: Distribution of the responses

\section{Conclusion and Recommendations}

The key findings of this study have been given below:

- The Duration of use of Facebook per day is 3-5 hours.

- The Duration of use of Facebook per login is 30 minutes by the target group.

- The Average friends' count of the target group is 500-1500.

- Facebook can be an essential e-learning tool for some reasons : Teachers provide the link, materials; Students can consult and get information from each other, Instant feedback, promote student collaboration, get updated materials, establishes the interaction between teachers and parents, A Highly motivating and entertaining platform of teaching, Shy students get confident, etc.

- Contribution for the development of social relationships: networking \& connectivity, an invitation to social events, charity and blood donors through Facebook, Reunite lost or old friends and alumni, learned experiences from alumni, creating social awareness, minimizing the cultural gap, etc. In making social bondage, few students are engaged with an online business. They show their extracurricular activities through the Facebook group, and by selling products, they earn some extra money.

- observed Facebook addictive symptoms are: insomnia, Spending time longer than planned, thinking about the next time login, Uncontrolled use by saying 'a few more minutes', feeling angry while internet access is unavailable etc

- Challenges or Threats: Falling victim of cyberbullying, blackmailing, fake profile, hacker, privacy issues etc

- Negative impact on Health: loneliness, depression, and other mental disorder, eye blur vision, headache, lack of face-to-face communication, sleep disorder.

- Most of the respondents are moderately addicted, and few are mildly addicted to Facebook.

Facebook is essentially a framework for socialization. Still, it can hold significant benefits for students, but use of Facebook can damage the learning process that should not be ignored. The distinct factor for students in their 
learning procedure is time, and this asset can contrarily be influenced by Facebook use. Facebook offers students many appeals that waste scores of their expensive time. If students were able to limit their usage of Facebook only to get in touch with friends on campus and to share academic information, Facebook could certainly contribute to their social belonging and security as well as to their learning process. This study also found that $37.9 \%$ of them do not want to use Facebook for business purposes because they think they are very often cheated by e-shopping.

Facebook benefits not only the students but also the teachers. It encourages collaborative learning, which leads to the achievement of a desirable outcome. Mutual discussions through social media increase the level of quality education. It strengthens both peer interactions and student-teacher interactions. Based on the results, the researcher recommends that instructors must encourage the students to use social sites academically. Instructors should persuade students to communicate with them using social sites if they are too shy to ask and get involved in the class. This study also suggests the idea of creating an online social group for elderly students to share experiences and help undergraduate students.

For academic and personal development, the researchers are recommending the students not to use social networking sites during their class time, late-night, and ignoring their personal, family, and social activities. Instead, they should ensure proper time management and balance, self-regulation, self-discipline in using these sites. Moreover, age limitation and introducing National Identity Card (NID) in using social networks may ensure control use of social networks among the students in Bangladesh.

As this study was conducted in a short time, it involved a tiny sample size comprising of only 150 individual student respondents who fall in the target group. The researcher purposively selected the respondents of the study on convenience and accessibility. A study with a larger sample size of randomly selected individuals who fulfill the criteria would be more representative. The study is limited to only Facebook as one of the representatives of Social Networking Sites. YouTube is becoming the next media, where everything now is available such as news, dramas, sports, even TV channels live, etc. So, most people are shifting the spending time of SNS from Facebook to YouTube. Researchers should include these other prominent SNSs in consideration to find the threats by SNS addiction.

\section{Recommendations:}

This study comes with the perception of the active students in their use of social media. The intrinsic impact of the social media is revealed by the study. A few recommendations can be drawn from the findings:

- Students should limit the use of social media temporally. Overuse of social media kills study time and causes health hazard.

- $\quad$ The use of social media at late night should be avoided as this habit impairs the natural biological clock and reduces workability at daytime.

- Access control in social media is important since the presence of appetizing gossips in political, communal and public groups in social media kills time.

- A use of social media in early morning is rather beneficial since it includes less internet traffic. However, the aim should be solely academic.

- Obsession with close groups should be avoided as it drags slowly in a different virtual world of its own which drifts our attention from normal human lives.

- Finally, exercise of freedom to use social media should be judged by individuals enthusiastically, not by force.

\section{References}

1. Alam, M. J. B., Kabir, S. M. L. I., \& Elizabeth, H. (2006). "E-Learning in Bangladesh: Implementation and evaluation of a pilot project". Proceedings of MMT 2006, Finland.

2. Anderson, T., “Social Networking." In S. Mishra (Ed.), E-Learning: STRIDE Handbook Vol 8 (pp. 96-101). New Delhi, 2010.

3. Asad, S., Mamun, M.A. and Clement, C.K. (2012) 'The Effect of Social Networking Sites to the Lifestyles of Teachers and Students in Higher Educational Institutions', International Journal of Basic and Applied Sciences, Vol. 1 Iss. 4, PP. 498-510.

4. Boyd, D., \& Ellison, N. (2007) 'Social Network Sites: Definition, History and Scholarship', Journal of ComputerMediated Communication, 13(1).

5. Brenner, V. (1997) 'Psychology of computer use: XLVII. Parameters of Internet use, abuse and addiction: The first 90 
days of the Internet usage survey', Psychological Reports, 80, pp. 879-882.

6. Connolly, M. (2011, October) 'Benefits and Drawbacks of Social Media in Education', Retrieved from Wisconsin Center for Education Research: http://www.wcer.wisc.edu/news/coverstories/2011/benefits_and_drawbacks.php

7. Ellison, N. B., Steinfield, C., \& Lampe, C., "The benefits of Facebook "friends:" Social capital and college students' use of online social network site". Journal of Computer Mediated Communication, Vol 11(2), (2007), article 2.

8. Ginsburg-Block, M. D., Rohrbeck, C. A., \& Fantuzzo, J. W., "A meta-analytic review of social, self-concept, and behavioral outcomes of peer-assisted learning”. Journal of Educational Psychology, Vol 98, (2006), pp.732-749

9. Helou, A.M., and Rahim N.Z.Ab., 2014, “The Influence of Social Networking Sites on Students' Academic Performance," International Journal of Electronic Commerce Studies, 5(2), pp. 247-254.

10. Kraut, R., Patterson, M., Lundmark, V., Kiesler, S., Mukophadhyay,T., \& Scherlis, W. (1998) 'Internet paradox: A social technology that reduces social involvement and psychological well-being?', American Psychologist, 53(9), pp. 10171031.

11. Larry D. Rosen., 2011a, "The Impact of Social Networks on Adolescents and Parents," Psychology Department, University of California, San Diego. Available at http://asbunplugged.org/larry-rosen.htm

12. Larry D. Rosen., 2011b, "Social Networking's Good and Bad Impacts on Kids," the 119th Annual Convention of the American Psychological Association, August 4-7, Walter E. Washington Convention Center: Washington D.C.

13. Mahmud, M. A. A. (2011) 'Student's Attitudes towards Internet: A study on Private University of Bangladesh', European Journal of Business and Management, Vol. 3 ISSN. 2222-1905(paper), ISSN 2222-2839 (online)

14. Mingle, J., \& Adams, M., 2015, "Social Media Network Participation and Academic Performance in Senior High Schools in Ghana," Library Philosophy and Practice (e-journal), pp.1-51.

15. Mohseni, M., Dowra, B. and Haghighat, M.H.S. (2008), 'Does the Internet Make People Socially Isolated?', A Social Network Approach, Bangladesh e-Journal of Sociology, Volume 5 Number 1. January 2008.

16. Mostofa, Sk. M. (2011) 'Internet Access and Use among Business Students of a Private University of Bangladesh: A Survey', Annals of Library and Information Studies, 58, 78-85.

17. Notley, T. M., \& Tacchi, J. A., "Online Youth Networks: Researching the Experiences of Peripheral Young People in Using New Media Tools for Creative Participation \& Representation in 3CMedia", Journal of Community, Citizens and Third Sector Media and Communication, Vol 1(1), (2005), pp.73-81

18. Rahman, S (2002) 'Internet in Bangladesh', at http://www.eela.com/computer/InternetBD_122202.html.

19. Roknuzzaman, M. (2006) 'A survey of Internet access in a large public university in Bangladesh', International Journal of Education and Development using Information and Communication Technology (IJEDICT), 2006, 2(3), 86-105.

20. Rosen, L. (2011, August) 'Poke Me: How Social Networks Can Both Help and Harm Our Kids', Washington, DC: American Psychological Association.

21. Selwyn. N. (2009). "Face working: Exploring students' education-related use of Facebook". Learning, Media and Technology, 2009, 34(2), 157-174.

22. Selwyn, N., "The digital native: myth and reality". ASLIB, Vol 61(4), (2009), pp.364-379

23. Sheldon, P., 2008, “Students Favorite: Facebook and Motives for Its Use," Southwestern Mass Communication Journal, 23(2), pp. 39-53.

24. Wang, Q., Chen, W. and Liang, Y. (2011) 'The Effects of Social Media on College Students. The Alan Shawn Feinstein Graduate School', Providence: Johnson \& Wales University.

25. Young, K. (1996) 'Internet addiction: The emergence of a new clinical disorder,' [Online], Available: http://www.pitt.edu/ ksy/apa.html.

26. Yunus, M., Nordin, N., Salehi, H., Embi, M. A., and Salehi, Z., 2013, "The Use of Information and Communication Technology in Teaching ESL Writing Skills,” English Language Teaching, 6(7), pp. 1-8.

27. Zwart, M. d., Lindsay, D., Henderson, M., \& Phillips, M. (2011) 'Teenagers, Legal Risks and Social Networking Sites', Victoria, Australia: Victoria Law Foundation.

\section{Appendix A1: Summary of Responses of all questions can be found in the next page of the article.}




\begin{tabular}{|c|c|c|c|c|c|c|c|c|c|}
\hline $\begin{array}{l}\text { SL } \\
\text { no }\end{array}$ & Question & $\begin{array}{c}\text { Strong } \\
\text { ly } \\
\text { Agree/ } \\
\text { Alway } \\
\text { s }\end{array}$ & $\begin{array}{c}\text { Agre } \\
\text { e/ } \\
\text { Ofte } \\
\text { n }\end{array}$ & $\begin{array}{c}\text { Neutral/ } \\
\text { Frequen } \\
\text { tly }\end{array}$ & $\begin{array}{c}\text { Disagree/ } \\
\text { Occasion } \\
\text { ally }\end{array}$ & $\begin{array}{c}\text { Strong } \\
\text { ly } \\
\text { Disagr } \\
\text { ee/ } \\
\text { Rarely }\end{array}$ & $\begin{array}{l}\text { Weight } \\
\text { ed } \\
\text { Score }\end{array}$ & $\begin{array}{c}\text { Ran } \\
\mathbf{k}\end{array}$ & $\begin{array}{l}\text { Quart } \\
\text { ile }\end{array}$ \\
\hline $\begin{array}{l}2.0 \\
2\end{array}$ & Do you believe that using social media in class can be time-consuming? & $4.5 \%$ & $\begin{array}{l}50.0 \\
\%\end{array}$ & $28.2 \%$ & $14.5 \%$ & $2.7 \%$ & 6.0 & 36 & 2 \\
\hline $\begin{array}{l}2.0 \\
4\end{array}$ & $\begin{array}{l}\text { Do you believe that social media is a highly motivating } \\
\text { and entertaining way of teaching, especially for university learners? }\end{array}$ & $5.4 \%$ & $\begin{array}{l}44.1 \\
\%\end{array}$ & $28.8 \%$ & $18.9 \%$ & $2.7 \%$ & 5.8 & 41 & 2 \\
\hline $\begin{array}{l}2.0 \\
5\end{array}$ & $\begin{array}{l}\text { Do you use social media to acquire required and non-required course-related } \\
\text { materials? }\end{array}$ & $15.3 \%$ & $\begin{array}{l}49.5 \\
\%\end{array}$ & $9.9 \%$ & $18.9 \%$ & $6.3 \%$ & 6.2 & 33 & 2 \\
\hline $\begin{array}{l}2.0 \\
6\end{array}$ & $\begin{array}{l}\text { Do you share and obtain information, links, or files through social media to } \\
\text { complete assignments? }\end{array}$ & $0.0 \%$ & $\begin{array}{l}50.9 \\
\%\end{array}$ & $28.2 \%$ & $20.9 \%$ & $0.0 \%$ & 5.8 & 42 & 2 \\
\hline $\begin{array}{l}2.0 \\
9\end{array}$ & $\begin{array}{l}\text { In Social media, students ask for help/advice on Assignments, solving problems, } \\
\text { projects etc. }\end{array}$ & $16.2 \%$ & $\begin{array}{l}60.4 \\
\%\end{array}$ & $10.8 \%$ & $9.0 \%$ & $3.6 \%$ & 6.9 & 15 & 2 \\
\hline $\begin{array}{l}2.1 \\
0\end{array}$ & $\begin{array}{l}\text { Do you think that, shy students feel hesitant to post and to be judged by teachers } \\
\text { and students? }\end{array}$ & $12.7 \%$ & $\begin{array}{l}66.7 \\
\%\end{array}$ & $11.8 \%$ & $6.9 \%$ & $2.0 \%$ & 7.0 & 13 & 2 \\
\hline \multirow[t]{2}{*}{$\begin{array}{l}2.1 \\
1\end{array}$} & Teachers provide link, materials to students through using social media. & $9.0 \%$ & $\begin{array}{l}72.1 \\
\%\end{array}$ & $13.5 \%$ & $4.5 \%$ & $0.9 \%$ & 7.1 & 12 & 2 \\
\hline & & & & & & & 6.3 & 30 & 2 \\
\hline $\begin{array}{l}2.1 \\
2\end{array}$ & Do you think that Shy students get confident in asking questions on Facebook? & $5.9 \%$ & $\begin{array}{l}54.9 \\
\%\end{array}$ & $24.5 \%$ & $13.7 \%$ & $1.0 \%$ & 6.7 & 21 & 2 \\
\hline $\begin{array}{l}2.1 \\
3\end{array}$ & $\begin{array}{l}\text { Do you agree that Students can consult and get information } \\
\text { from each other about lecture summaries, ask questions, etc.? }\end{array}$ & $6.9 \%$ & $\begin{array}{l}66.7 \\
\%\end{array}$ & $19.6 \%$ & $1.0 \%$ & $5.9 \%$ & 7.5 & 4 & 1 \\
\hline $\begin{array}{l}\text { SL } \\
\text { no }\end{array}$ & Question & $\begin{array}{c}\text { Strong } \\
\text { ly } \\
\text { Agree/ } \\
\text { Alway } \\
\text { s }\end{array}$ & $\begin{array}{c}\text { Agre } \\
\text { e/ } \\
\text { Ofte } \\
\text { n }\end{array}$ & $\begin{array}{c}\text { Neutral/ } \\
\text { Frequen } \\
\text { tly }\end{array}$ & $\begin{array}{l}\text { Disagree/ } \\
\text { Occasion } \\
\text { ally }\end{array}$ & $\begin{array}{c}\text { Strong } \\
\text { ly } \\
\text { Disagr } \\
\text { ee/ } \\
\text { Rarely }\end{array}$ & $\begin{array}{l}\text { Weight } \\
\text { ed } \\
\text { Score }\end{array}$ & $\begin{array}{c}\text { Ran } \\
\mathbf{k}\end{array}$ & $\begin{array}{l}\text { Quart } \\
\text { ile }\end{array}$ \\
\hline $\begin{array}{l}2.1 \\
4\end{array}$ & $\begin{array}{l}\text { In the Facebook group, answers are saved, so students can look them up later. } \\
\text { Do you agree? }\end{array}$ & $18.6 \%$ & $\begin{array}{l}66.7 \\
\%\end{array}$ & $10.8 \%$ & $2.9 \%$ & $1.0 \%$ & 6.3 & 29 & 2 \\
\hline $\begin{array}{l}2.1 \\
5\end{array}$ & $\begin{array}{l}\text { One of Facebook's important effect is that conversation moved } \\
\text { from Facebook to Class, Class to Facebook. How often do you agree this? }\end{array}$ & $17.6 \%$ & $\begin{array}{l}46.1 \\
\%\end{array}$ & $15.7 \%$ & $12.7 \%$ & $7.8 \%$ & 6.8 & 18 & 2 \\
\hline $\begin{array}{l}2.1 \\
6\end{array}$ & $\begin{array}{l}\text { Do you think that, because of Instant feedback, it can be an essential e-learning } \\
\text { tool? }\end{array}$ & $8.8 \%$ & $\begin{array}{l}66.6 \\
\%\end{array}$ & $15.7 \%$ & $5.9 \%$ & $1.0 \%$ & 4.4 & 58 & 3 \\
\hline $\begin{array}{l}2.1 \\
7\end{array}$ & $\begin{array}{l}\text { Do you face problems regarding uploading and downloading word files or PDF } \\
\text { on Facebook? }\end{array}$ & $12.7 \%$ & $\begin{array}{l}28.4 \\
\%\end{array}$ & $12.7 \%$ & $14.7 \%$ & $31.4 \%$ & 7.3 & 9 & 2 \\
\hline $\begin{array}{l}2.1 \\
8\end{array}$ & $\begin{array}{l}\text { Do you think that you would have better grades if you spent less time on } \\
\text { Facebook? }\end{array}$ & $23.5 \%$ & $\begin{array}{l}54.9 \\
\%\end{array}$ & $14.7 \%$ & $2.9 \%$ & $3.9 \%$ & 6.4 & 27 & 2 \\
\hline $\begin{array}{l}2.1 \\
9\end{array}$ & Teachers make announcements about deadlines on Facebook. & $9.9 \%$ & $\begin{array}{l}52.3 \\
\%\end{array}$ & $24.3 \%$ & $12.6 \%$ & $0.9 \%$ & 6.6 & 24 & 2 \\
\hline $\begin{array}{l}2.2 \\
0\end{array}$ & On Facebook, Students get help or support with solving a problem. & $4.9 \%$ & $\begin{array}{l}69.6 \\
\%\end{array}$ & $14.7 \%$ & $5.9 \%$ & $4.9 \%$ & 5.7 & 44 & 2 \\
\hline $\begin{array}{l}2.2 \\
1\end{array}$ & Do you think that, Facebook is time-consuming for teachers? & $3.9 \%$ & $\begin{array}{l}36.3 \\
\%\end{array}$ & $44.1 \%$ & $13.7 \%$ & $2.0 \%$ & 6.1 & 34 & 2 \\
\hline $\begin{array}{l}2.2 \\
2\end{array}$ & Do you think that, SNSs provide necessary sources to prepare notes? & $2.9 \%$ & $\begin{array}{l}40.2 \\
\%\end{array}$ & $53.9 \%$ & $2.0 \%$ & $1.0 \%$ & 6.7 & 19 & 2 \\
\hline $\begin{array}{l}2.2 \\
4\end{array}$ & Do you think that Facebook promotes student collaboration? & $6.9 \%$ & $\begin{array}{l}59.8 \\
\%\end{array}$ & $29.4 \%$ & $3.9 \%$ & $0.0 \%$ & 6.6 & 23 & 2 \\
\hline $\begin{array}{l}2.2 \\
5\end{array}$ & Do you think that Facebook users devoted lesser time to their studies? & $8.8 \%$ & $\begin{array}{l}56.9 \\
\%\end{array}$ & $25.5 \%$ & $6.9 \%$ & $2.0 \%$ & 6.2 & 32 & 2 \\
\hline $\begin{array}{l}2.2 \\
6\end{array}$ & $\begin{array}{l}\text { Do you agree that excessive use of Social Networking Sites users scored lower } \\
\text { grades? }\end{array}$ & $6.9 \%$ & $\begin{array}{l}50.0 \\
\%\end{array}$ & $31.4 \%$ & $8.8 \%$ & $2.9 \%$ & 6.4 & 28 & 2 \\
\hline $\begin{array}{l}\text { SL } \\
\text { no }\end{array}$ & Question & $\begin{array}{c}\text { Strong } \\
\text { ly } \\
\text { Agree/ } \\
\text { Alway } \\
\text { s }\end{array}$ & $\begin{array}{c}\text { Agre } \\
\text { e/ } \\
\text { Ofte } \\
\text { n }\end{array}$ & $\begin{array}{c}\text { Neutral/ } \\
\text { Frequen } \\
\text { tly }\end{array}$ & $\begin{array}{c}\text { Disagree/ } \\
\text { Occasion } \\
\text { ally }\end{array}$ & $\begin{array}{c}\text { Strong } \\
\text { ly } \\
\text { Disagr } \\
\text { ee/ } \\
\text { Rarely }\end{array}$ & $\begin{array}{c}\text { Weight } \\
\text { ed } \\
\text { Score }\end{array}$ & $\begin{array}{c}\text { Ran } \\
\mathbf{k}\end{array}$ & $\begin{array}{l}\text { Quart } \\
\text { ile }\end{array}$ \\
\hline $\begin{array}{l}2.2 \\
7\end{array}$ & $\begin{array}{l}\text { Do you think that social media is the best way for teachers to reach all the } \\
\text { students? }\end{array}$ & $13.7 \%$ & $\begin{array}{l}49.0 \\
\%\end{array}$ & $19.6 \%$ & $15.7 \%$ & $2.0 \%$ & 6.0 & 35 & 2 \\
\hline $\begin{array}{l}2.2 \\
8\end{array}$ & $\begin{array}{l}\text { Do you think that Social Media establishes the interaction between teachers and } \\
\text { parents? }\end{array}$ & $4.9 \%$ & $\begin{array}{l}46.1 \\
\%\end{array}$ & $35.3 \%$ & $10.8 \%$ & $2.9 \%$ & 7.4 & 5 & 2 \\
\hline $\begin{array}{l}3.0 \\
1\end{array}$ & $\begin{array}{l}\text { How often do you choose Facebook for chatting and } \\
\text { audio and video call rather than other social networking sites? }\end{array}$ & $37.8 \%$ & $\begin{array}{l}31.5 \\
\%\end{array}$ & $23.4 \%$ & $4.5 \%$ & $2.7 \%$ & 7.4 & 8 & 2 \\
\hline $\begin{array}{l}3.0 \\
3\end{array}$ & Do you think that Facebook is easy, convenient, $24 / 7$ communication? & $13.7 \%$ & $\begin{array}{l}68.6 \\
\%\end{array}$ & $16.7 \%$ & $1.0 \%$ & $0.0 \%$ & 6.9 & 16 & 2 \\
\hline $\begin{array}{l}3.0 \\
4\end{array}$ & $\begin{array}{l}\text { Do you think that using Facebook, students develop a social relationship with } \\
\text { each other? }\end{array}$ & $11.8 \%$ & $\begin{array}{l}65.7 \\
\%\end{array}$ & $11.8 \%$ & $7.8 \%$ & $2.9 \%$ & 7.4 & 7 & 2 \\
\hline $\begin{array}{l}3.0 \\
5\end{array}$ & Students could communicate with alumni through Facebook. Do you agree? & $16.7 \%$ & $\begin{array}{l}70.6 \\
\%\end{array}$ & $7.8 \%$ & $1.0 \%$ & $3.9 \%$ & 6.7 & 20 & 2 \\
\hline $\begin{array}{l}3.0 \\
6\end{array}$ & How often do you use Facebook to upload or get updated or awareness? & $24.5 \%$ & $\begin{array}{l}44.1 \\
\%\end{array}$ & $16.7 \%$ & $5.9 \%$ & $8.8 \%$ & 7.8 & 3 & 1 \\
\hline $\begin{array}{l}3.0 \\
7\end{array}$ & $\begin{array}{l}\text { Facebook is a Social Networking site for quick communication. Do you think } \\
\text { so? }\end{array}$ & $22.5 \%$ & $\begin{array}{l}70.6 \\
\%\end{array}$ & $4.9 \%$ & $1.0 \%$ & $1.0 \%$ & 6.9 & 14 & 2 \\
\hline $\begin{array}{l}3.0 \\
8\end{array}$ & $\begin{array}{l}\text { How often do you find cooperation linked to noble } \\
\text { social cause (charity or blood donors) through Facebook? }\end{array}$ & $29.7 \%$ & $\begin{array}{l}43.2 \\
\%\end{array}$ & $10.8 \%$ & $7.2 \%$ & $9.0 \%$ & 8.0 & 2 & 1 \\
\hline $\begin{array}{l}3.0 \\
9\end{array}$ & How often do you prefer Facebook as a source of Current News? & $52.3 \%$ & $\begin{array}{l}27.9 \\
\%\end{array}$ & $10.8 \%$ & $4.5 \%$ & $4.5 \%$ & 6.6 & 25 & 2 \\
\hline $\begin{array}{l}3.1 \\
0\end{array}$ & Do you think that Social Networking Sites minimize the cultural gap? & $7.8 \%$ & $\begin{array}{l}56.9 \\
\%\end{array}$ & $25.5 \%$ & $9.8 \%$ & $0.0 \%$ & 8.3 & 1 & 1 \\
\hline
\end{tabular}




\begin{tabular}{|c|c|c|c|c|c|c|c|c|c|}
\hline $\begin{array}{l}\text { SL } \\
\text { no }\end{array}$ & Question & $\begin{array}{c}\text { Strong } \\
\text { ly } \\
\text { Agree/ } \\
\text { Alway } \\
\text { s }\end{array}$ & $\begin{array}{c}\text { Agre } \\
\text { e/ } \\
\text { Ofte } \\
\text { n }\end{array}$ & $\begin{array}{l}\text { Neutral/ } \\
\text { Frequen } \\
\text { tly }\end{array}$ & $\begin{array}{l}\text { Disagree/ } \\
\text { Occasion } \\
\text { ally }\end{array}$ & $\begin{array}{c}\text { Strong } \\
\text { ly } \\
\text { Disagr } \\
\text { ee/ } \\
\text { Rarely }\end{array}$ & $\begin{array}{l}\text { Weight } \\
\text { ed } \\
\text { Score }\end{array}$ & $\begin{array}{c}\operatorname{Ran}_{\mathbf{k}} \\
0\end{array}$ & $\begin{array}{l}\text { Quart } \\
\text { ile }\end{array}$ \\
\hline $\begin{array}{l}3.1 \\
1\end{array}$ & Does Facebook act as magic in reuniting with old friends or lost friends? & $56.8 \%$ & $\begin{array}{l}30.6 \\
\%\end{array}$ & $4.5 \%$ & $5.4 \%$ & $2.7 \%$ & 6.8 & 17 & 2 \\
\hline $\begin{array}{l}3.1 \\
2\end{array}$ & Social media is beneficial in arranging social events, to build up public opinion. & $13.7 \%$ & $\begin{array}{l}60.8 \\
\%\end{array}$ & $17.6 \%$ & $0.0 \%$ & $7.8 \%$ & 7.1 & 11 & 2 \\
\hline $\begin{array}{l}3.1 \\
3\end{array}$ & $\begin{array}{l}\text { Do you think that, Social Networking Sites are useful to solve communication } \\
\text { problems? }\end{array}$ & $11.8 \%$ & $\begin{array}{l}64.7 \\
\%\end{array}$ & $19.6 \%$ & $3.9 \%$ & $0.0 \%$ & 7.4 & 6 & 2 \\
\hline $\begin{array}{l}3.1 \\
4\end{array}$ & $\begin{array}{l}\text { Do you think that, Social Networking Sites can be a } \\
\text { helpful mode of sharing experiences and research findings? }\end{array}$ & $14.7 \%$ & $\begin{array}{l}70.6 \\
\%\end{array}$ & $10.8 \%$ & $3.9 \%$ & $0.0 \%$ & 7.2 & 10 & 2 \\
\hline $\begin{array}{l}3.1 \\
5\end{array}$ & Social Networking Sites create awareness. Do you agree? & $11.8 \%$ & $\begin{array}{l}69.6 \\
\%\end{array}$ & $14.7 \%$ & $2.9 \%$ & $1.0 \%$ & 6.7 & 22 & 2 \\
\hline $\begin{array}{l}4.0 \\
1\end{array}$ & Do you find Facebook helpful in finding online job circulars? & $29.7 \%$ & $\begin{array}{l}37.8 \\
\%\end{array}$ & $10.8 \%$ & $12.6 \%$ & $9.0 \%$ & 3.3 & 63 & 3 \\
\hline $\begin{array}{l}4.0 \\
2\end{array}$ & Do you use Facebook for running a business page? & $11.7 \%$ & $\begin{array}{l}22.3 \\
\%\end{array}$ & $4.3 \%$ & $9.6 \%$ & $52.1 \%$ & 3.8 & 62 & 3 \\
\hline $\begin{array}{l}4.0 \\
3\end{array}$ & Do you earn some extra money running business page in Facebook? & $0.0 \%$ & $\begin{array}{l}14.9 \\
\%\end{array}$ & $35.1 \%$ & $37.2 \%$ & $12.8 \%$ & 4.0 & 60 & 3 \\
\hline $\begin{array}{l}4.0 \\
5\end{array}$ & Do you have confidence in online shopping through social media? & $9.8 \%$ & $\begin{array}{l}30.4 \\
\%\end{array}$ & $6.9 \%$ & $15.7 \%$ & $37.3 \%$ & 5.4 & 47 & 2 \\
\hline $\begin{array}{l}4.0 \\
6\end{array}$ & Do you think that, engaging in online business hamper your study? & $2.0 \%$ & $\begin{array}{l}35.3 \\
\%\end{array}$ & $40.2 \%$ & $21.6 \%$ & $1.0 \%$ & 1.4 & 64 & 2 \\
\hline $\begin{array}{l}5.0 \\
1\end{array}$ & How often have you been a victim of Facebook account hacking? & $2.7 \%$ & $\begin{array}{l}10.8 \\
\%\end{array}$ & $4.5 \%$ & $5.4 \%$ & $76.6 \%$ & 5.3 & 50 & 2 \\
\hline $\begin{array}{l}5.0 \\
2\end{array}$ & $\begin{array}{l}\text { While using Facebook, how often have you been a victim of cyber-harassment } \\
\text { or blackmailing? }\end{array}$ & $5.4 \%$ & $\begin{array}{l}35.1 \\
\%\end{array}$ & $28.8 \%$ & $27.0 \%$ & $3.6 \%$ & 3.8 & 61 & 3 \\
\hline $\begin{array}{l}5.0 \\
3\end{array}$ & $\begin{array}{l}\text { How often do you suffer from deterioration in health due to the uncontrolled use } \\
\text { of Facebook? }\end{array}$ & $8.1 \%$ & $\begin{array}{l}24.3 \\
\%\end{array}$ & $13.5 \%$ & $19.8 \%$ & $34.2 \%$ & 4.0 & 59 & 3 \\
\hline $\begin{array}{l}5.0 \\
4\end{array}$ & While using Facebook, how often have you faced privacy issues? & $7.2 \%$ & $\begin{array}{l}14.4 \\
\%\end{array}$ & $32.4 \%$ & $23.3 \%$ & $21.6 \%$ & 5.8 & 39 & 2 \\
\hline $\begin{array}{l}\text { SL } \\
\text { no }\end{array}$ & Question & $\begin{array}{c}\text { Strong } \\
\text { ly } \\
\text { Agree/ } \\
\text { Alway } \\
\text { s }\end{array}$ & $\begin{array}{c}\text { Agre } \\
\text { e/ } \\
\text { Ofte } \\
\text { n }\end{array}$ & $\begin{array}{c}\text { Neutral/ } \\
\text { Frequen } \\
\text { tly }\end{array}$ & $\begin{array}{l}\text { Disagree/ } \\
\text { Occasion } \\
\text { ally }\end{array}$ & $\begin{array}{c}\text { Strong } \\
\text { ly } \\
\text { Disagr } \\
\text { ee/ } \\
\text { Rarely }\end{array}$ & $\begin{array}{l}\text { Weight } \\
\text { ed } \\
\text { Score }\end{array}$ & $\underset{\mathbf{k}}{\operatorname{Ran}}$ & $\begin{array}{c}\text { Quart } \\
\text { ile }\end{array}$ \\
\hline $\begin{array}{l}5.0 \\
5\end{array}$ & $\begin{array}{l}\text { How often do you find Facebook as wastage of valuable time? } \\
\text { Do you lose track of time when you are on Facebook? }\end{array}$ & $16.2 \%$ & $\begin{array}{l}39.6 \\
\%\end{array}$ & $17.1 \%$ & $14.4 \%$ & $12.6 \%$ & 5.4 & 46 & 2 \\
\hline $\begin{array}{l}5.0 \\
6\end{array}$ & Do you feel that Facebook is distracting your attention from your family? & $21.6 \%$ & $\begin{array}{l}28.8 \\
\%\end{array}$ & $17.1 \%$ & $10.8 \%$ & $21.6 \%$ & 4.5 & 57 & 3 \\
\hline $\begin{array}{l}5.0 \\
7\end{array}$ & How often have been disturbed by Fake accounts? & $12.6 \%$ & $\begin{array}{l}28.8 \\
\%\end{array}$ & $14.4 \%$ & $14.4 \%$ & $29.7 \%$ & 4.6 & 56 & 3 \\
\hline $\begin{array}{l}5.0 \\
8\end{array}$ & How often do you scroll Facebook to forget your problems? & $11.7 \%$ & $\begin{array}{l}33.3 \\
\%\end{array}$ & $11.7 \%$ & $13.5 \%$ & $29.7 \%$ & 5.0 & 52 & 2 \\
\hline $\begin{array}{l}5.0 \\
9\end{array}$ & Do you feel that Facebook has hurt your academic,personal or Career? & $14.4 \%$ & $\begin{array}{l}29.7 \\
\%\end{array}$ & $17.1 \%$ & $19.8 \%$ & $18.9 \%$ & 5.3 & 49 & 2 \\
\hline $\begin{array}{l}5.1 \\
0\end{array}$ & For using Facebook, how often do you ignore household chores? & $9.9 \%$ & $\begin{array}{l}44.1 \\
\%\end{array}$ & $13.5 \%$ & $13.5 \%$ & $18.9 \%$ & 4.8 & 53 & 3 \\
\hline $\begin{array}{l}5.1 \\
1\end{array}$ & $\begin{array}{l}\text { How often do you have insomnia due to being active on Facebook till late at } \\
\text { night? }\end{array}$ & $7.2 \%$ & $\begin{array}{l}36.0 \\
\%\end{array}$ & $18.0 \%$ & $18.0 \%$ & $20.7 \%$ & 4.7 & 54 & 3 \\
\hline $\begin{array}{l}5.1 \\
2\end{array}$ & How often do you catch yourself thinking about next time you will log in? & $9.0 \%$ & $\begin{array}{l}32.4 \\
\%\end{array}$ & $21.6 \%$ & $12.6 \%$ & $24.3 \%$ & 6.2 & 31 & 2 \\
\hline $\begin{array}{l}5.1 \\
3\end{array}$ & Do you ever feel "a few more minutes" when you are logged into Facebook? & $25.2 \%$ & $\begin{array}{l}34.2 \\
\%\end{array}$ & $19.8 \%$ & $6.3 \%$ & $14.4 \%$ & 5.5 & 45 & 2 \\
\hline $\begin{array}{l}5.1 \\
4\end{array}$ & $\begin{array}{l}\text { Students are concerned about being misled by their classmates' inaccurate } \\
\text { postings. }\end{array}$ & $0.9 \%$ & $\begin{array}{l}30.6 \\
\%\end{array}$ & $57.7 \%$ & $8.1 \%$ & $2.7 \%$ & 5.9 & 38 & 2 \\
\hline $\begin{array}{l}5.1 \\
5\end{array}$ & Do you feel too much addiction to Social Media? & $26.1 \%$ & $\begin{array}{l}27.0 \\
\%\end{array}$ & $18.0 \%$ & $12.6 \%$ & $16.2 \%$ & 5.9 & 37 & 2 \\
\hline $\begin{array}{l}5.1 \\
6\end{array}$ & $\begin{array}{l}\text { How often do you feel Headache, Eye problem, stress and dark circle for } \\
\text { excessive use of Facebook? }\end{array}$ & $18.0 \%$ & $\begin{array}{l}30.6 \\
\%\end{array}$ & $30.6 \%$ & $12.6 \%$ & $8.1 \%$ & 5.4 & 48 & 2 \\
\hline $\begin{array}{l}\text { SL } \\
\text { no }\end{array}$ & Question & $\begin{array}{c}\text { Strong } \\
\text { ly } \\
\text { Agree/ } \\
\text { Alway } \\
\text { s }\end{array}$ & $\begin{array}{c}\text { Agre } \\
\text { e/ } \\
\text { Ofte } \\
\text { n }\end{array}$ & $\begin{array}{c}\text { Neutral/ } \\
\text { Frequen } \\
\text { tly }\end{array}$ & $\begin{array}{c}\text { Disagree/ } \\
\begin{array}{c}\text { Occasion } \\
\text { ally }\end{array}\end{array}$ & $\begin{array}{c}\text { Strong } \\
\text { ly } \\
\text { Disagr } \\
\text { ee/ } \\
\text { Rarely }\end{array}$ & $\begin{array}{l}\text { Weight } \\
\text { ed } \\
\text { Score }\end{array}$ & $\begin{array}{c}\text { Ran } \\
\mathbf{k}\end{array}$ & $\begin{array}{c}\text { Quart } \\
\text { ile }\end{array}$ \\
\hline $\begin{array}{l}5.1 \\
7\end{array}$ & $\begin{array}{l}\text { How often do you suffer from the emotional problems, } \\
\text { mental depression, lack of face- to- face communication due to use of Facebook? }\end{array}$ & $11.7 \%$ & $\begin{array}{l}30.6 \\
\%\end{array}$ & $32.4 \%$ & $11.7 \%$ & $13.5 \%$ & 5.8 & 40 & 2 \\
\hline $\begin{array}{l}5.1 \\
8\end{array}$ & $\begin{array}{l}\text { Do you think that social media violates your privacy and makes you vulnerable } \\
\text { to extortion? } \\
\text { Is your personal data confidential, secret and reliable on social media? }\end{array}$ & $5.4 \%$ & $\begin{array}{l}39.6 \\
\%\end{array}$ & $36.9 \%$ & $16.2 \%$ & $1.8 \%$ & 6.5 & 26 & 2 \\
\hline $\begin{array}{l}5.1 \\
9\end{array}$ & $\begin{array}{l}\text { Do you think virtual social media negatively affects real } \\
\text { social communication such as family, friends, and relatives? }\end{array}$ & $11.7 \%$ & $\begin{array}{l}51.4 \\
\%\end{array}$ & $23.4 \%$ & $12.6 \%$ & $0.9 \%$ & 4.7 & 55 & 3 \\
\hline $\begin{array}{l}5.2 \\
0\end{array}$ & $\begin{array}{l}\text { Do you always become frustrated and angry when social networks are } \\
\text { unavailable? }\end{array}$ & $5.4 \%$ & $\begin{array}{l}35.1 \\
\%\end{array}$ & $28.8 \%$ & $3.6 \%$ & $5.3 \%$ & 5.7 & 43 & 2 \\
\hline $\begin{array}{l}5.2 \\
1\end{array}$ & $\begin{array}{l}\text { How often do you think that Excessive use of social networks is keeping you } \\
\text { aloof from a family tie? }\end{array}$ & $13.5 \%$ & $\begin{array}{l}41.4 \\
\%\end{array}$ & $20.7 \%$ & $8.1 \%$ & $16.2 \%$ & 5.1 & 51 & 2 \\
\hline $\begin{array}{l}5.2 \\
2\end{array}$ & $\begin{array}{l}\text { Are you living a virtual life as Excessive use of social networks is isolating you } \\
\text { from real life? }\end{array}$ & $9.9 \%$ & $\begin{array}{l}24.3 \\
\%\end{array}$ & $29.7 \%$ & $30.6 \%$ & $5.4 \%$ & 6.0 & 36 & 2 \\
\hline
\end{tabular}

